\title{
LENDO "BARBA AZUL" NA SALA DE LEITURA DA ESCOLA: AS PRÁTICAS DE LEITURA E A EXPERIÊNCIA COM A LITERATURA
}

\section{LECTURA "BARBA AZUL" EN LA SALA DE LECTURA DE LA ESCUELA: PRÁCTICAS DE LECTURA Y EXPERIENCIA DE LITERATURA}

\section{READING "BLUE BEARD" IN THE SCHOOL READING ROOM: READING AND LITERATURE TEACHING PRACTICES}

\section{Sônia Maria Milhone Travassos ${ }^{1}$ Patricia Corsino ${ }^{2}$}

Resumo: Este artigo parte de discussões de uma tese que analisou o trabalho com a literatura infantil da sala de leitura de uma escola pública. Na introdução, defende a ideia da leitura literária enquanto experiência que permanece no leitor. Em seguida, discute práticas sociais de leitura que atravessaram o tempo e que, ao serem ressignificadas na escola, podem favorecer a interlocução das crianças com a literatura. Por fim, analisa eventos nos quais uma professora realiza com seus alunos a leitura oralizada do conto Barba Azul, de Perrault, abrindo espaços de conversas sobre ele e contribuindo para a formação leitora de todos.

Palavras-chave: literatura; sala de leitura; práticas de leitura; escola.

Resumen: Este artículo parte de las discusiones de una tesis que analiza el trabajo con literatura infantil en la sala de lectura de una escuela pública. En la introducción, defiende la idea de la lectura literaria como una experiencia que permanece en el lector. Luego analiza las prácticas de lectura social que se han cruzado con el tiempo y que, cuando se vuelven a indicar en la escuela, pueden favorecer el diálogo de los niños con la literatura. Finalmente, analiza eventos en los que una maestra conduce con sus alumnos la lectura oral del Cuento Barba Azul de Perrault, abriendo espacios para conversaciones al respecto y contribuyendo a la formación de lectura de todos.

Palabras clave: literatura; sala de lectura; prácticas de lectura; escuela

\begin{abstract}
This article starts from discussions of a thesis that analyzed the work with children's literature in the reading room of a public school. In the introduction, he defends the idea of literary reading as an experience that remains in the reader. Em seguida, discute práticas sociais de leitura que atravessaram o tempo e que, ao serem ressignificadas na escola, podem favorecer a interlocução das crianças com a literatura. Finally, it analyzes events in which a teacher conducts with her students the oral reading of Perrault's short story Barba Azul, opening spaces for conversations about him and contributing to the reading formation of all.
\end{abstract}

\footnotetext{
${ }^{1}$ Mestre e Doutora em Educação (UFRJ), Especialista em Literatura Infantil e Juvenil (UFRJ), dinamizadora de leitura, escritora e contadora de histórias. E-mail: soniamariatravassos@gmail.com

${ }^{2}$ Mestre e Doutora em Educação pela PUC-Rio. Professora do Programa de Pós-graduação em Educação da UFRJ. E-mail: corsinopat@gmail.com
} 
Keywords: literature; reading room; reading practices; school.

\section{Introdução}

Dentro dos jardins gelados que rodeavam suas terras, amulher enterrou as outras esposas de Barbazul para que suas almas descansassem em paz Junto dos túmulos plantou centenas de flores vermelhas, para que todos se lembrassem delas para sempre (LOPEZ, 2017, s/p)

Barba Azul, uma história escrita por Charles Perraut (1628-1703), ao ser recontada por Anabella Lopez, mais de trezentos anos depois de sua primeira edição, ganha este final transcrito na epígrafe. Num gesto de sororidade, a última mulher de Barba Azul enterra as outras mulheres mortas e enfeita seus túmulos com flores vermelhas, para que sejam lembradas. $\mathrm{O}$ conto clássico é interpretado e ganha contornos atuais num livro de projeto gráfico bem cuidado, que apresenta um texto contemporâneo conciso e uma ilustração criativa e autoral com cores escuras, traço firme, formas simples, que não se propõem a mostrar tudo que é narrado, mas sim sugerir e deixar espaços abertos para o leitor estabelecer uma relação dialógica com o texto verbal. O livro identificado como uma produção de literatura infantil extrapola seus leitores presumidos e ganha outros pelo tratamento estético. Mas o que teria neste conto que ainda hoje faz pensar sobre a condição feminina? O que faz da literatura este espaço de tempo suspenso que se abre à experiência? Por que ler literatura? Qual é o lugar da literatura na escola? Que práticas podem fazer da leitura literária uma experiência?

Este artigo tem como objetivo discutir possibilidades da leitura literária na escola junto a crianças dos anos iniciais do ensino fundamental. Foi organizado em quatro partes. $\mathrm{Na}$ primeira, aborda a leitura literária na escola como possibilidade de se constituir como experiência. Na segunda e na terceira parte discute algumas práticas sociais de leitura que também se encontram presentes no trabalho com a literatura na escola, especialmente as leituras orais compartilhadas e as rodas de leitura. Na quarta, apresenta análises de encontros entre crianças dos primeiros anos de ensino fundamental com o conto "Barba Azul" (Charles Perrault), evento de leitura que faz parte do material empírico da tese de doutorado de uma das autoras. Finaliza, tecendo considerações sobre a presença da leitura literária na escola.

\section{Leitura, Literatura, Experiência e Escola}


Partimos do pressuposto de que a leitura literária tem uma dimensão formativa relacionada à experiência benjaminiana, como aquilo que vai além do momento em que se realiza, que provoca e desloca o leitor. Para Benjamin (1994), é pela narrativa que as pessoas intercambiam experiências, quando contam sua história a outros, deixam nos ouvintes marcas, rastros de sua experiência no mundo. Crítico da modernidade, e do entendimento da história como uma marcha linear de progresso da humanidade, Benjamin refuta à ideia de progresso por entender que todo monumento de cultura é também um monumento de barbárie, já que depende de quem conta a história. E esta tem sido contada pelas vozes dos vencedores. A narrativa tem a possibilidade de trazer para o tempo presente as vozes dos vencidos, rompendo com o a linearidade da história e mudando o seu curso. Com o desvio é possível escovar a história à contrapelo e mudar o futuro. Para Benjamin, a narrativa, própria do trabalho artesanal, foi sendo substituída pela informação, que traz a explicação e deixa pouco espaço para troca entre os sujeitos. A falta de narrativa empobrece a experiência humana e leva à alienação da linguagem. O tecer das narrativas é um importante meio de não se perder a história, de não se descartar o passado, de se intercambiar experiências vividas e de se estabelecer elos de coletividade. Para o filósofo, passado, presente e futuro se interligam por meio da narrativa, pois podemos recuperar o passado, colocá-lo em questão no presente e alterar o futuro. Quando a linguagem expressiva cede lugar à linguagem informativa e instrumental, há menos possibilidades para nos conhecermos, nos reconhecermos ou nos estranharmos na experiência do outro.

Estas questões nos instigam a pensar a escola como um possível contexto para se narrar, tanto experiências acontecidas, quanto histórias inventadas. De acordo com a perspectiva do filósofo, a narrativa potencializa o imaginário, atua sobre a subjetividade e contribui para que não apenas se reproduza a cultura, mas que se possa recriá-la. Na Educação Infantil e nos anos iniciais do Ensino Fundamental, a narração de histórias costuma fazer parte do cotidiano escolar. Porém, uma pergunta se coloca: quando se narram histórias para as crianças, há tempo para que, nas interações propostas, elas troquem e teçam experiências? Diferentes pesquisas evidenciam que há uma preocupação excessiva da escola em checar o entendimento superficial e objetivo das crianças acerca do que foi ouvido/lido, em práticas que abreviam o espaço para o imaginário e para o diálogo do leitor com o texto e com outros leitores. Como comenta Reyes (2012), ler um conto de fadas não é o mesmo que ler um manual de instruções. Mas é essa concepção que muitas vezes impera no ensino da literatura:

Para entender um conto, é necessário conectá-lo com sensações, emoções, [...], zonas secretas de nossa experiência. Se não nos permitimos explorar essas zonas secretas 
com suas penumbras e suas ambiguidades, esses contos não nos dirão nada, de modo que serão feitas perguntas como qual o tema do texto, quando nasceram seus autores, ou o que identificamos na introdução (REYES, 2012, s.p.).

Reyes se reporta à experiência de leitura dos Contos de Fadas, mas suas reflexões fazem pensar no trabalho que se desenvolve nas escolas com a leitura de qualquer texto literário. Uma pergunta se coloca: será que em práticas que tratam os textos literários como manuais de instrução, o leitor leva rastros do que foi vivido no momento da leitura para fora do tempo imediato? Como comenta Kramer (2009), “a leitura levada pelo sujeito para além do dado imediato permite pensar, ser crítico da situação, relacionar o antes e o depois, entender a história, ser parte dela, continuá-la, modificá-la, redirecioná-la” (p. 33 e 34). Também compreendendo a leitura literária como experiência, Yunes (2009), afirma que as palavras criam realidades, tornando reais muitas coisas, mas as palavras também fazem coisas conosco, podendo nos tocar, nos fazer sentir e pensar, nos modificar. Para que façamos uma experiência, efetivamente, "não basta que algo aconteça, mas nos aconteça" (p. 38). Pois quando algo nos acontece, saímos do lugar comum para vermos as coisas de outra forma, saímos "ao encontro do outro com a disposição do diálogo" (idem, p. 38).

A partir das reflexões acima, ressaltamos duas questões que se colocam lado a lado quando problematizamos a experiência com a literatura na escola: que obras nós escolhemos e como as compartilhamos com as crianças. Qualquer obra literária é capaz de ampliar a experiência do sujeito/leitor? Abrimos espaço para o diálogo para além do momento de leitura vivido? Para a construção de sentidos?

Nos debates em torno do ato de ler literatura, Cosson (2006) afirma que ler promove a troca de sentidos entre o escritor e o leitor, "mas também com a sociedade onde ambos estão localizados, pois os sentidos são resultado de compartilhamentos de visões do mundo entre os homens no tempo e no espaço" (p.27). Que práticas de leitura presentes na escola podem contribuir para as trocas e produção de sentidos dos leitores, lembrando que a escola é um espaço coletivo? Como elas podem favorecer as interações entre os leitores e os textos, os leitores e o mundo e ainda entre os diferentes leitores? Para Yunes (2009), "não há ato de leitura e de conhecimento que não se dê na interação leitor/texto, pessoa/mundo" (p. 32). E completa:

As interações produzem uma zona movente de sentidos, que se constitui dos contextos múltiplos em que se inserem, segundo focos e perspectivas. O universo do discurso (a língua posta em uso) deixa ver/ouvir diferentes vozes, animadas por distintas ideologias, que atravessam os textos e os falantes (YUNES, 2009, p.32). 
Ao refletirmos sobre o texto literário, vale ressaltar que a literatura é parte inseparável da cultura, da história e do contexto social de cada época e se apresenta de forma mais polissêmica e polifônica do que textos de outras áreas do conhecimento: polissêmicos, porque passíveis de diferentes leituras, dependendo da história de vida do leitor, sua visão de mundo etc. e, polifônicos, porque na voz do autor estão as vozes de outras pessoas, de outros autores, da sociedade, da história. Para Goulart (2007), no discurso literário "se hibridizam muitas linguagens sociais, muitos gêneros, muitos sujeitos, apresentando a sociedade de forma viva, pulsante, contraditória, estetizando e arquitetando a linguagem de modos diversos" (p.64).

Assim, defendemos a experiência/ensino da literatura na escola como caminho para a formação do leitor: ao abrir-se a múltiplas interpretações e sentidos, a literatura permite o encontro do leitor com si mesmo e com o outro, com contextos e realidades diversas, podendo promover experiências que permaneçam, transformem e ampliem os referenciais das crianças. Como ressalta Goulart (2007), a literatura se constitui como fonte para a formação de leitores críticos: "vivendo o desafio de interpretar vazios, ambiguidades, novas relações, novos modos de viver, conhecer, fazer e falar. A abertura de janelas no texto literário torna-o um grande hipertexto" (p.64).

Importante lembrar que na escola, muitas vezes, os encontros dos leitores crianças com a literatura acontecem de forma mediada pelo professor adulto, o qual poderá lançar mão de variadas práticas sociais de leitura para promovê-los. Trazemos a seguir práticas de leitura presentes no trabalho com a literatura na escola para depois analisarmos encontros entre crianças dos primeiros anos de ensino fundamental com o conto "Barba Azul" (Charles Perrault), uma prática de leitura desenvolvida numa escola que foi campo da pesquisa de tese de doutorado de uma das autoras.

\section{Práticas de leitura}

"Em que medida ocorrências institucionais aguçam curiosidades, procura de respostas, desejos de ler?" - já questionava Perrotti, nos idos de 1990. Como a escola pode criar ações que levem os leitores à participação, à crítica, ao desejo de buscar conhecimentos, de descobrir, de ler? Não só na escola, mas pela vida afora, e numa sociedade onde a escrita se faz presente e essencial? Como conceber os leitores como sujeitos da cultura, capazes de criar e reelaborar experiências e informações obtidas por meio da leitura, se apropriando desta? 
Tais questões nos fazem buscar Chartier (2009), quando o autor se remete à ideia de apropriação da leitura como invenção - com o leitor fazendo algo novo com aquilo que recebe, interpretando, refletindo, dialogando com o texto - e, assim, construindo sentidos. De acordo com o historiador, o leitor seria "um caçador que percorre terras alheias" (CHARTIER, p. 77), que tem liberdade para subverter aquilo que o livro, o texto, a "terra alheia" lhe pretende apresentar. Porém, essa liberdade não seria absoluta e sim “cercada por limitações derivadas das capacidades, convenções e hábitos que caracterizam, em suas diferenças, as práticas de leitura" (idem, p. 77).

Mas o que podemos compreender por práticas de leitura? As práticas de leitura estão associadas ao ato de ler que, por sua vez, relaciona-se com ações culturais aprendidas em diferentes sociedades:“Ações culturais aqui se referem a toda manifestação histórica do homem que contrasta com o naturalmente dado. [...] práticas culturais pressupõem tanto a criação humana quanto as heranças culturais transmitidas pelas gerações passadas" (CABRAL, 2008 p. 51). Nessa direção, ressalta ainda que a leitura e a escrita são produções da experiência humana que a história social promoveu e, "do ponto de vista da aprendizagem, correspondem a práticas valorizadas na transmissão cultural” (idem, p. 71).

Ao refletir sobre as práticas culturais associadas à leitura, Cabral (2010) destaca a importância de compreendê-la como algo que envolve mais de um sujeito. De um lado o autor, cujo texto que produz é criado a partir de seu acervo particular de leitura e do acervo cultural coletivo da sociedade em que está inserido. Do outro, há o leitor que, ao ler, "precisa acionar a sua memória discursiva, o acervo de leitura construído, os textos que fazem parte do repertório cultural, de modo a propor hipóteses de sentidos válidas para o tecido de palavras que tem diante de si” (CABRAL, 2008, p. 51). Além desse movimento do leitor frente ao discurso do texto, que envolve conhecimento linguístico, memória discursiva e ações culturais, há outros elementos que podem interferir na produção de sentidos quando se está diante de um livro impresso: o projeto gráfico, a encadernação, as ilustrações, a diagramação, o tipo de papel elementos que constituem a sua materialidade e impõem também uma forma de ler.

As reflexões sobre o ato de ler e sobre as práticas de leitura que se perpetuaram e se modificaram com o tempo, em diferentes modos de ler - em silêncio, oralmente, com os olhos, com os ouvidos, em grupos, solitariamente, de forma mimética - são inúmeras. Segundo Chartier (2009), ao longo do tempo e dos lugares, os gestos de leitura mudaram, assim como os objetos lidos e as razões de ler: 
Do rolo antigo ao códex medieval, do livro impresso ao eletrônico, várias rupturas maiores dividem a longa história das maneiras de ler. Elas colocam em jogo a relação entre o corpo e o livro, os possíveis usos da escrita e as categorias intelectuais que asseguram sua compreensão (p.77).

A leitura vem sendo objeto de estudo de vários campos e ocupa um lugar importante nas problematizações a respeito da educação contemporânea. De uma maneira geral, considerase a leitura como uma experiência que envolve situações de produção de sentido, provocando o leitor a estabelecer relações com o contexto do qual faz parte e com ele próprio. Mas quais seriam as práticas de leitura que favoreceriam a interlocução entre os leitores e as leituras, provocando-os a serem ativos diante daquilo que leem? É importante o desenvolvimento de práticas que ofereçam aos leitores "a possibilidade de estabelecer relações com seus conhecimentos e experiências prévias, com outros textos já lidos, com o contexto histórico, em exercício do pensamento e de adequação ao meio em que vive” (p. 122). Dentre as práticas sociais de leitura que se perpetuaram ao longo do tempo - solitárias, coletivas, silenciosas, orais, intensivas dos mesmos textos -, extensivas de textos numerosos -, destacaremos duas que se apresentam frequentemente no universo escolar, numa tentativa de favorecer a interlocução das crianças com a literatura: a leitura oral compartilhada e as rodas ou círculos de leitura.

Comecemos pela leitura oral e compartilhada de histórias impressas em livros e que nos remete imediatamente às práticas orais e coletivas de outros tempos, quando aquele que dominava melhor a leitura lia em voz alta para os que ainda não tinham a mesma habilidade. Tomando hoje a relação professor/alunos, podemos dizer que estamos vivenciando aquela mesma prática, quando nem todos de numa mesma comunidade eram letrados, ou mesmo antes, em práticas ancestrais de contação de histórias, em sociedades onde a escrita nem se fazia presente, mas nas quais as narrativas compartilhadas promoviam o intercambiar de experiências, como nos diria o filósofo Walter Benjamin (1994).

A prática de narrar histórias, orais e escritas, está presente no cotidiano de muitas escolas e demanda um cuidado nem sempre considerado pelos professores. É comum, quando se trata de ler um livro impresso, retirar-se qualquer exemplar da prateleira, sem nenhum tipo de preparo para conhecer o que se apresentará às crianças, correndo-se o risco de se narrar uma história que pouco contribuirá para o intercâmbio entre os leitores. Para escolher o que ler para e com as crianças será sempre relevante indagar: por que aquela seria uma boa história para ser narrada? Que tipo de experiência ela poderia trazer para os ouvintes? Pois a literatura, como muitos pesquisadores afirmam, seria um instrumento para ver e ouvir o outro, proporcionando ao leitor um exercício de alteridade e que contribui para sua constituição enquanto sujeito. Por 
isso também, a escolha de uma história escrita a ser lida exige um olhar criterioso sobre sua qualidade literária. Corsino et al (2017) discutem tal qualidade a partir da articulação entre três artes:

\begin{abstract}
i) da palavra - que inclui a literariedade; ii) das artes visuais - ilustração; e iii) do design gráfico - que engloba o projeto gráfico-editorial da obra. Articulação compreendida, de acordo com Bakhtin (2003), como interdiscursividade entre as linguagens verbal e visual, numa estreita e indissociável relação entre forma e conteúdo. Interdiscursividade que inclui a presença das diferentes vozes que compõem os textos verbal e visual. [...] o livro de literatura infantil considerado de qualidade seria aquele em que as diferentes vozes em interlocução se abrem discursivamente ao leitor, que responde ao produzir sentido e se desloca afetado pela experiência estética (p. 27-28).
\end{abstract}

Importante ressaltar que, para além da escolha da história a ser narrada, a prática da leitura oral compartilhada demanda um olhar especial para o próprio momento onde se dará o encontro entre o professor, a história e o ouvinte/leitor: é nele que sentimentos, pensamentos, descobertas, lembranças podem aflorar e ser partilhados, ao longo da narrativa ou depois, por meio de olhares, gestos, indagações, conversas, desenhos, representações etc. O papel do professor/narrador, na performance de sua leitura, é outro ponto a que se deve estar atento, pois é ele que empresta sua voz, seus olhares, emoções e sensações para cada instante da história e que, na intimidade que constrói com o texto, descobre seu ritmo, o tom que dará a cada personagem, as modalidades da voz, as pausas, os suspenses, a exploração do humor, das rimas, etc., algo que favorece certamente a interação do leitor com o texto, seu deslocamento e a elaboração de sentidos. Mais do que ser um mediador de leitura, o professor é aquele lê para e com seus alunos, é aquele que "compartilha a leitura com seus ouvintes, deixando-se afetar por ela também" (TRAVASSOS, 2010. P. 69).

Há ainda uma questão a se ressaltar sobre esta prática de leitura que muitos denominam de "A Hora do Conto" e que aponta para reflexões sobre a inter-relação entre oralidade e escrita no trabalho com a literatura junto a crianças. Podemos considerar a ação de ler e de contar histórias como a mesma estratégia para o compartilhamento da leitura? Para Corsino (2010), contar e ler histórias são duas práticas fundamentais, porém distintas: “contam-se histórias de muitas formas, usando diferentes recursos e leem-se histórias que estão nos livros” (p. 192). De acordo com a pesquisadora, o livro infantil cada vez mais vem recebendo um tratamento editorial que visa uma articulação entre forma, conteúdo, texto verbal, ilustração - elementos que contribuem para a interação das crianças com a história e que precisam ser apreciados por elas no momento de uma leitura coletiva. Afirma ainda que a leitura oral de um texto literário 
seria como uma porta que se abriria ao texto escrito, ideia que também é compartilhada por Amarilha (1997). Para esta autora a leitura oral da literatura contribui para o acesso à língua em articulações próprias da linguagem escrita, já que a linguagem literária se propõe a organizar os fatos em forma diferente da linguagem oral do cotidiano: "como essa roupagem tem bossa, ritmo, humor, o leitor mirim percebe estar diante de uma maneira diferente de ser da língua" (AMARILHA, p. 49) e ressalta que o ritmo das frases, o jogo da sonoridade, a arrumação das palavras são para as crianças pontos de referência no acesso à escrita.

Sobre a diferenciação entre ler ou contar histórias, Debus (2002) comenta que a leitura do texto literário e a contação de histórias são, ambas, práticas importantes no compartilhamento da literatura. Para a autora, a contação de histórias permite o contato com narrativas mais extensas que, se lidas pelo adulto, poderiam se tornar cansativas; no entanto, comenta, a leitura do texto escrito possibilita à criança a proximidade com o padrão culto da língua: "Se nas histórias contadas [...] ganham ênfase as expressões gestual e facial, na leitura em voz alta prevalece o uso correto da língua, o que possibilita à criança interagir com um vocabulário mais rico, ampliando as suas habilidades linguísticas” ( $\mathrm{s} / \mathrm{n})$.

Já para Britto (2005, p. 5), ao ouvir a leitura oral de um texto escrito, a criança pequena estaria lendo com os ouvidos, aprendendo também as modulações de voz que se enunciam num texto escrito. A criança, como defende o autor, estaria aprendendo a voz escrita, a sintaxe escrita, as palavras escritas:

\footnotetext{
Nesse sentido, as crianças são capazes de ouvir histórias longas, mais interessantes que esses textos de frases soltas. Se lermos uma história com (com e não para) uma criança que não conhece o sistema da escrita e pedirmos para ela recontar o que leu, ela certamente não dirá a história com as mesmas palavras do texto original, nem reproduzirá o enredo em sua exatidão, mas demonstrará que compreendeu o texto (que reagiu a ele). Demonstrará, enfim, que leu e o resignificou (BRITTO, 2005, p. 5).
}

Outra prática de leitura coletiva presente no trabalho de muitas escolas são as que denominamos de "Círculos" ou "Rodas de Leitura". Prática que resgata antigos hábitos de ler coletivamente e que, como aborda Silva (2008), aponta para a dimensão social da leitura: ler coletivamente para debater ideias, se posicionar, pensar as questões do mundo etc. Nas Rodas, os participantes leem simultaneamente um mesmo texto ou o leitor-guia lê em voz alta a obra escolhida e o restante do grupo o acompanha em outros exemplares dela. O importante das "Rodas" é que, ao final da leitura, este leitor-guia instigue os demais participantes a pensarem sobre o que leram, levantando questões a serem debatidas e estimulando-os a trocarem suas impressões. Esta troca amplia a leitura dos participantes da Roda, que, ao perceberem aspectos 
do texto, nas vozes de outros leitores, podem elaborar novas interpretações para ele. O papel do "leitor-guia", como Yunes (2009) compreende, seria o daquele que costura as falas de todos os participantes, sem deixar que sua voz prevaleça sobre as outras. No debate de ideias surgidas a partir de uma leitura comum, também é possível cruzar diferentes leituras, comparando a que está sendo discutida com outras já conhecidas ou que podem vir a ser conhecidas pelos leitores. O que se desejaria alcançar com os "Círculos" seria "a descoberta da condição do leitor e uma qualificação maior para a leitura, por conta mesmo da troca, do intercâmbio, da interação de vivências e histórias de leitura - segundo o repertório de cada um, como diria Iser" (YUNES, 2009, p. 82).

Wolfang Iser, citado por Yunes, é importante teórico da Estética da Recepção, linha de estudos que busca compreender o que acontece com o ouvinte/leitor no ato da leitura de um texto literário. Nessa teoria, "o intervalo entre o texto e o leitor é fundamental, já que se admite que o texto é processado na leitura" (SILVA, 2008, p. 70). Permeados de lacunas e negações, os textos seriam negociados no ato da leitura, e seriam estas negociações de sentido que permitiriam "transplantar o texto para a consciência do leitor" (idem, p. 70). Segundo Silva (2008), porém, a teoria da recepção de Iser coloca maior ênfase na interação (sempre imprevisível) entre um texto ficcional e uma consciência individual, não dando conta da dimensão social da leitura, como a que se constitui nas atividades de círculos de leitura. Para ele, para se compreender a dinâmica destes, os estudos de Stanley Fish, trariam maiores contribuições. Nessa visão:

\begin{abstract}
os leitores criam os textos e não os interpretam, e o sentido atribuído a um texto é criado cognitivamente pelo leitor, pertencente a uma comunidade interpretativa. [...] leitores pertencentes à determinada comunidade interpretativa constroem textos semelhantes de acordo como as concepções, valores e conceitos compartilhados por sua comunidade; ao mesmo tempo, leitores inseridos em comunidades interpretativas diferentes irão construir outros textos (SILVA, 2008, p. 71).
\end{abstract}

Ler, interpretar, produzir sentidos, construir novos textos a partir da experiência com a leitura literária, individualmente e coletivamente, faz parte do trabalho com a literatura que pode ser desenvolvido na escola. A leitura silenciosa e individual permite que o processo interpretativo de um leitor sofra talvez menos influência externa do que quando ela é realizada coletivamente, embora um leitor nunca entre sozinho numa leitura: o leitor mergulha numa nova leitura com sua bagagem de leituras, com sua história e experiência de vida, com seus valores e conceitos sobre o mundo, com as vozes que o constituem, com suas ideologias elementos que o influenciarão na elaboração deste ou daquele sentido. Vale ressaltar que em 
qualquer situação de leitura o leitor é livre para pensar, sentir e se afetar pelo que lê, porém, na leitura silenciosa, ele não precisará dividir suas impressões com ninguém, o que é diferente do que acontece nas rodas de leitura, quando o espaço para as trocas se constitui como o elemento principal para a realização deste tipo de prática leitora.

\section{As práticas de leitura e a literatura na sala de leitura da escola}

Este artigo tem como objetivo trazer algumas reflexões e análises tecidas no âmbito da tese de doutorado de uma das autoras, que teve como uma de seus objetivos conhecer e analisar as práticas de leitura desenvolvidas em salas de leitura escolares, cujos trabalhos conquistaram visibilidade e reconhecimento na própria comunidade escolar e junto à secretaria de educação do município do Rio de Janeiro. Ao longo do trabalho de campo da tese, ficou bastante claro que a maior parte das práticas de leitura vivenciadas na Sala de Leitura se remetia a práticas com a literatura, com seu compartilhamento e ensino. Nesse sentido, procuramos observar que concepções (de infância, de leitura, de literatura) as atravessavam e como as vozes das crianças se faziam ouvir nos momentos de interlocução propostos.

Foi possível perceber que as práticas de leitura que mais adentravam o cotidiano das duas salas de leitura investigadas eram as leituras orais de histórias, realizadas pelas professoras, as leituras livres das crianças e os empréstimos de livros. Rodas de comentários, nas quais os alunos poderiam falar sobre as leituras realizadas em casa, a partir dos empréstimos, pouco se apresentaram. Já as rodas e círculos de leitura, marcavam maior presença, por meio de pequenas conversas, provocadas por alguma indagação da professora ou comentário espontâneo das crianças, em meio às leituras orais compartilhadas. Embora a rodas de leitura não parecessem ser muito planejadas pelas professoras, como meio de fazer ampliações da leitura realizada, elas estavam entre suas preocupações. Numa conversa informal com a professora Elza, por exemplo, ela diz achar importante dialogar mais sobre as histórias ouvidas, para que as crianças pudessem trocar mais ideias, no entanto, afirma que elas não estariam muito familiarizadas com esse tipo de atividade. Para exemplificar sua reflexão, conta uma conversa que desenvolveu a partir da leitura de diferentes versões de "Chapeuzinho Vermelho", quando procurou discutir a atualidade ou não de seu enredo, provocando as crianças a pensarem sobre questões de hoje que se relacionavam com as da narrativa. Nessa conversa, comenta sobre a dificuldade de conduzir essa atividade, embora as crianças estivessem envolvidas pelo tema: "Eu pego sempre os $5^{\circ}$ anos, mas eles estão mais acostumados a ficar só 
escrevendo. Então, quando têm que conversar sobre o que leram, é difícil. Eu saí daqui rouquinha" (caderno de campo, 23/05/17).

Conversar sobre histórias ouvidas coletivamente, o que se assemelha às rodas e círculos de leitura, é uma prática a qual muitos professores recorrem para dar continuidade à leitura das crianças. E como Brandão e Rosa (2010) ressaltam, um primeiro ponto que justificaria a importância desta prática seria "a possibilidade que ela dá de engajar o leitor ou ouvinte na busca e produção de significados sobre o que lê ou escuta" (p. 70), levando-o a compreender que, para tanto, é preciso interagir ativamente com o texto, pensar sobre ele, indagá-lo, sentilo. No trecho que destacamos com a reflexão de Elza, percebe-se tanto a intenção da professora em promover rodas de conversa, como as dificuldades que encontra nessa pratica. Nesse sentido, torna-se ainda mais importante pensar na forma de planejar e conduzir esses momentos, o que se inicia pela escolha do texto que se quer compartilhar, mas que implica outras preparações. Como Bajour (2013) sinaliza: “pensar nos textos com antecedência é imaginar perguntas, modos de apresentar e adentrar os livros" (p. 60). O que trazer para provocar a conversa? O que e como perguntar para provocar os leitores a continuarem indagando o texto lido ou ouvido, como fazer inferências e abrir espaço para as diferentes vozes dialogarem, inclusive a do professor, escutando e reagindo às diferentes respostas e aos imponderáveis que delas podem surgir?

As rodas de conversa ou rodas de leitura são práticas sociais que atravessaram os tempos e continuam sendo praticadas hoje, vide os clubes e comunidades de leitores que se espalham pela cidade: reunir grupos para conversar sobre um texto, na escola ou fora dela, pode mobilizar os sujeitos em muitas direções, provocando-os, nesse encontro com o outro, a trocar experiências e estreitar os laços da coletividade, como diria Benjamin. Nas rodas de leitura, o papel do professor, além de provocar discussões sobre as temáticas do texto, poderá ainda “chamar a atenção para aspectos da narrativa, não percebidos de imediato pelo grupo, analisando o tratamento literário dado ao texto, no que se refere ao gênero, linguagem, tempo, ambiente, narrador, personagens, ampliando assim o saber de seus alunos sobre o fazer literário" (TRAVASSOS, 2010, p. 69).

As salas de leitura investigadas apresentaram-se como espaços para a ampliação da experiência de leitura dos alunos, sendo impulsionada principalmente pelo trabalho realizado com a literatura. Nesse sentido, é pertinente problematizar, para além do observado na tese, as razões de se ler e de se ensinar a ler literatura, na escola. Por que e para que lemos literatura na 
escola? De acordo com Britto (2012), literatura é uma expressão da arte e arte seria “a expressão de um desejo de construir e viver mundos e vidas outras; nesse processo, ela realiza o gesto de voltar-se para dentro de si e indagar a condição humana" (BRITTO, p.53). Nesse sentido, a arte seria contemplação e indagação da vida, opondo-se ao simples entretenimento. Mas como a literatura vem sendo partilhada nas escolas? Como arte? Como entretenimento? Para fins didáticos? Qual o lugar da literatura e do ensino dela na escola?

Cosson (2010) nos socorre nessas reflexões, chamando a atenção para o fato de que o ensino da literatura na escola variou ao longo do tempo, apontando para diferentes usos que se fizeram dela: como forma de ampliar a cultura das elites, a partir da leitura dos cânones, para realizar exercícios gramaticais, tomando a língua apenas como um objeto ou, quando se tinha o contato com a leitura da obra, criando-se exercícios ligados ao preenchimento de fichas, reduzindo o conhecimento literário a listas sem sentido de nomes, datas, estilos de época, etc. Nesse tipo de ensino, a prática com a leitura das obras era muitas vezes realizada em fragmentos encontrados em livros didáticos, dificultando as possíveis relações a serem estabelecidas entre leitores e textos literários, o que, de acordo com ele, teria resultado "no progressivo encurtamento da presença da literatura na escola" (COSSON, p.57). No entanto, esse encurtamento não significaria a ausência da literatura na escola:

por algum tempo, até mesmo por causa da vitalidade da literatura infantil e juvenil
brasileira, as obras literárias foram usadas não como objeto de ensino, mas de simples
fruição. Buscava-se reproduzir na escola o mesmo comportamento do leitor maduro
em relação ao texto literário. O prazer de ler, uma proposta muitas vezes mal
interpretada, foi bandeira de muitos daqueles que viam no ensino da literatura um
cerceamento da leitura literária, esquecendo que todo modo de ler passa
necessariamente por uma aprendizagem, não existindo um modo "natural" ou
espontâneo de leitura. Aos poucos, entretanto, o ler por ler foi cedendo lugar a uma
compreensão mais elaborada da relação entre literatura e ensino (COSSON, 2010,
p. 57).

A partir dessas reflexões, Cosson (2010) questiona qual seria então o lugar da literatura na escola? Como tornar o ensino da literatura uma prática significativa e não apenas prazerosa e efêmera? Nesse sentido, reivindica "um espaço próprio para a literatura na sala de aula" (idem, p. 57), afirmando que este se apresenta em três possibilidades: o espaço do texto, o espaço do contexto e o espaço do intertexto. Sobre o primeiro desses espaços, esclarece que ele pode ser compreendido como o espaço para a leitura do texto literário e que não deve servir de pretexto para outras aprendizagens. Para o autor, o texto literário tem seu lugar garantido quando é lido e discutido de forma a ampliar a compreensão dos leitores sobre ele: "Tudo se inicia com o imprescindível e motivado contato com a obra. Ler o texto literário em casa, na biblioteca ou 
em sala de aula, silenciosamente ou em voz alta, com ou sem a ajuda do professor, permite o primeiro encontro do leitor com o texto" (idem, p. 58).

Será especialmente sobre esse primeiro espaço do texto literário na escola - ler o texto na sala de leitura - que nos debruçaremos na próxima parte deste artigo, analisando momentos da leitura oral e compartilhada do conto "Barba Azul" (Perrault), e nos quais, algumas das conversas que ocorreram sobre ele, caminharam na direção daquilo que Cosson chama de espaço de contexto.

\section{Lendo e conversando sobre o conto "Barba Azul": análises de eventos da pesquisa}

Numa das salas de leitura investigadas, suas professoras, para ampliarem o projeto de leitura de clássicos que acontecia na escola como um todo, também nas salas de aula, optaram por trabalhar especialmente com os contos de Charles Perrault, em adaptações bem cuidadas e cujos textos se aproximavam bastante das versões originais. Acompanhamos diferentes momentos da leitura do conto "Barba Azul" (numa adaptação de Fernanda Lopes de Almeida e com ilustrações de Elizabeth Teixeira) e que, por apresentar um texto um pouco mais longo, como no original, foi lido em partes. Vejamos o primeiro evento analisado:

\section{Conversando com Barba Azul: imaginação, sentimentos, reflexões}

Entra uma turma de $4^{\circ}$ ano e Amélia os organiza para ouvirem a história do Barba Azul. No início as crianças estão dispersas, mas Amélia conta a história muito bem e vai envolvendo todos nos acontecimentos do conto. Quando ela narra a parte do quarto onde todas as mulheres do Barba Azul estão mortas e penduradas, as crianças pedem para ver a ilustração. “Tia, mostra!” Mas Amélia continua a leitura, com bastante suspense. Em sua performance, muda o tom da voz, levanta, se aproxima dos alunos, fala em direção a um e a outro... Na parte em que a mulher do Barba Azul está pedindo ajuda da irmã para salvá-la e o marido está ficando cada vez mais bravo, Amélia lê com entusiasmo, dando vida aos dois personagens pela voz, e as crianças adoram. Então, antes do desfecho, ela para a leitura e pergunta: "E, agora? Será que ela vai se salvar? O que será que vai acontecer?" Todas as crianças falam ao mesmo tempo: "os irmãos vão chegar e salvar ela!”; "ele vai matar ela!”; "ela vai conseguir fugir!” Não consigo anotar tudo o que as crianças falam, mas são muitas as suposições (caderno de campo, 11/04/17).

O que está em jogo quando se lê uma história para uma criança? O que está em jogo quando se ouve um conto tradicional, que atravessou séculos, alimentando a imaginação dos leitores? Para analisar esse primeiro recorte das leituras que presenciamos do conto "Barba Azul", partimos de questões já discutidas por diferentes estudiosos da literatura infantil e da infância: Abramovich (1989), por exemplo, diria que ler e ouvir histórias são formas de suscitar o imaginário, de conhecer outros lugares, de sentir emoções importantes. Sisto (s/ano, p.1) diria 
que ao ouvir uma história, a criança vivencia no plano psicológico as ações, os problemas, os conflitos dessa história e que essa vivência "por empréstimo" aumentaria o repertório de conhecimentos dela. Corsino (2010) diria que ouvir e contar histórias que nos aconteceram e que aconteceram com o outro, reais ou imaginárias, ajudaria a formar nossas subjetividades e, aos nos reconhecermos e nos estranharmos no outro, nos faria intercambiar experiências. Reyes (2012) diria que ler um conto de fadas ou outros textos literários não seria o mesmo que ler uma receita, que ler literatura envolve sentimentos, lembranças etc.: para ela, um professor de leitura é uma voz que conta, "uma mão que abre portas e traça caminhos entre a alma dos textos e a alma dos leitores" (REYES, p.28). Muitos outros pesquisadores poderiam ser "chamados" aqui para "dizerem" desse momento e dos sentidos de ler e ouvir histórias, mas para a análise desse evento, trazemos um dizer de Rodari (1982): a criança não se interessa apenas pelo conteúdo da história que lhe é narrada, mas pelas/nas formas como isso acontece, na voz do leitor/contador, na sua modulação, no seu volume, que embala, "que comunica ternura, que desata os nós da inquietação" (p. 116).

A professora lê em voz alta um texto literário, cuja linguagem verbal que o constitui tem a capacidade de instaurar realidades e explorar os sentidos. No entanto, o mergulho nessa nova realidade que se coloca, é provocado também, e principalmente, pela forma como ela é apresentada aos ouvintes, nos modos de ler da professora: sua voz, seus volumes e tons, seus olhares e movimentos convocam seus ouvintes a abrir portas e adentrar os caminhos do conto, junto com ela. Sim. Junto com ela. Porque como Vargas (2008) sublinha, contar histórias é, antes de tudo, compartilhar. O contador/leitor precisa acreditar no que está narrando para, no ritmo de sua leitura, abrir espaço para o ouvinte imaginar o inimaginável: “o conto só ganha corpo e existe quando é materializado na imaginação do ouvinte e do contador" (p.29), afirma $\mathrm{o}$ autor. E foi isso que vimos acontecer. As crianças estavam dispersas, mas, convidadas pela leitura da professora, começam a imaginar o inimaginável junto com ela, o sultão, a mulher do sultão, as mulheres mortas e penduradas, mergulhando dessa forma no conto, agora materializado na imaginação de cada um. Chama a atenção o momento em que uma aluna pede para ver, no livro que Amélia lia, o "inimaginável” das mulheres mortas e penduradas: esse desejo de buscar a ilustração para completar, ampliar ou mesmo acreditar naquilo que fora ouvido, nos faz ressaltar a ideia de que as leituras das crianças passam pelo ouvir, pelo imaginar, pelo sentir, mas também pelo tocar, pelo ver e pelo apreciar. Que diferença teria feito para a leitura e compreensão das crianças que pediram -“Tia, mostra!” -, não temos como saber, 
embora possamos imaginar, pois como Pimentel (2012) afirma: "antes de ler as palavras, as crianças leem com as imagens. Os livros e suas ilustrações dão suporte semântico, permitindo a partilha de significados” (p. 7). Mas o fato é que Amélia não mostrou a ilustração, continuando a desatar os nós daquela viagem coletiva, no tom e intenções que imprimia ao texto, conseguindo "engravidar as palavras de sentido" (VARGAS, 2008, p. 29).

Este evento também apresenta um momento em que a interação verbal acontece a partir da provocação da professora. Ao parar a leitura num momento chave da história, caso de vida ou morte, e indagar se a personagem se salvaria, provoca as crianças a expressarem os sentidos que estavam atribuindo ao conto, socializando-os com os demais leitores: "os irmãos vão chegar e salvar ela!”; “ele vai matar ela!”; "ela vai conseguir fugir!”. Abre-se nesse momento espaço para que a voz de cada leitor, nas possibilidades que apresentam a respeito da continuidade da cena, possa ampliar a dos demais. É nesse sentido que buscamos um diálogo com Bakhtin (1988), para quem nossas respostas são contrapalavras às palavras do outro. São réplicas que procuram completar, sugerir, concordar, discordar, ampliar as enunciações do outro, em busca de maior compreensão sobre elas: "compreender a enunciação de outrem significa orientar-se em relação a ela, encontrar o seu lugar adequado no contexto correspondente" (BAKHTIN, 1988, p. 132). Para responder à indagação da professora, as crianças apresentaram réplicas, que iam sendo expressas como respostas às reveladas antes, como numa corrente de enunciações, na qual os elos vão se interligando uns aos outros, envolvendo diferentes sujeitos, suas percepções, seus desejos e seus modos de olhar a realidade em suas inúmeras possibilidades frente a qualquer situação. Contar oralmente uma história, como Sisto (s/ano, p.2) ressalta, é uma forma de reunir, criar intimidade e agregar as pessoas, num ato que promove encontros consigo próprio, com o outro, com o universo imaginário e, por extensão, com a realidade.

A leitura da mesma história para outra turma de $4^{\circ}$ ano suscitou novas indagações em torno do desfecho final. Alguns meninos apresentaram réplicas aos acontecimentos da narrativa, respondendo à professora, mas também ao texto (estes outros que com eles entram em relação): "o sultão tinha que ter sido mais castigado!”; "enforcado!”; "faca no pescoço!”; “ele morreu muito rápido!". Nos momentos em que fizeram tais enunciações, chegaram a sair dos lugares de onde ouviam a história, na urgência de exporem suas visões sobre o ocorrido e serem ouvidos pela professora e pelo grupo. Yunes (2009, p. 32), como destacado antes, afirma que não há ato de leitura que não se dê na interação leitor/texto, pessoa/mundo - o que nos faz pensar sobre o evento aqui descrito: como se deu a interação leitor/texto com esses alunos? Que 
reflexões eles teceram a respeito do universo lido/ouvido? Como se posicionaram a partir delas? Como as relacionaram com a realidade que conhecem, para além do contexto da narrativa? Como compreendemos, as leituras serão sempre diferentes de um leitor para o outro, pois cada leitor só pode estabelecer relações com o mundo que conhece. Ao expressar uma opinião, revelar um posicionamento, sugerir novas formas de agir em relação ao ocorrido, as crianças se diferem, pois suas histórias de vida, seus valores e horizontes sociais também são diversos e interferem no modo de interpretarem e se colocarem no mundo. O ato de ler sempre implicará tanto na troca de sentidos entre o escritor e o leitor, como com a sociedade onde ambos estão localizados. Assim, como o sultão deveria morrer? Com mais ou menos sofrimento? Por quê? O que seria "adequado" para punir sua perversidade? Como se lida com situações cruéis no mundo real? As enunciações dos meninos, feitas de forma contundente, revelam seus olhares sobre questões que estão no mundo real. Nesse sentido, ao conversarem com o conto, adentrando seu universo imaginário construindo significados para ele, vão buscando atribuir sentidos ao mundo e à própria a vida. Dito isto, passemos ao segundo evento, com a leitura oral do conto Barba Azul, para outra turma, e que nos provocou novas perspectivas de análise:

\section{Conversando com Barba Azul: suspense e emoção de corpo inteiro}

Amélia começa a ler a história do Barba Azul. A maioria das crianças está atenta; na hora em que a personagem entra no quarto proibido e se depara com as esposas mortas e penduradas, uma aluna, antes que Amélia acabasse de narrar a cena, tampa os ouvidos e cobre a cabeça com a blusa, para não ver e nem ouvir mais nada. Amélia continua a leitura, explorando as vozes e entonações. No auge da história, interrompe a leitura e indaga às crianças sobre o que poderá acontecer. Nesse momento, um aluno que estava bem atento diz para o colega ao lado: "Ela só vai terminar na outra aula, quer ver? Ela já fez isso!" Quando Amélia realmente diz que só lerá o final na aula seguinte, ele diz para o colega: viu? (caderno de campo, 11/04/17).

Ao ser criado na e pela linguagem, o universo literário caracteriza-se pela possibilidade de instaurar realidades, reinventar o mundo e explorar os sentidos dos leitores, permitindo a vivência da alteridade e a experimentação de sentimentos. Logo no início do segundo evento da leitura de "Barba Azul" observamos os movimentos de uma aluna - já capturada pela e para a realidade do conto, quase que misturada a seus acontecimentos e personagens, sentindo junto com eles seus medos e expectativas. O que acontece é que, no momento em que ela ouve a narração sobre a personagem entrando no quarto proibido e se deparando com a terrível cena das ex-mulheres do sultão mortas e dependuras, não aguenta tanta tensão e cobre olhos e ouvidos, se escondendo, fugindo como pôde da cena que está sendo narrada, tão horrorizada como a personagem foge dentro conto. 
Para analisar esse movimento da aluna, buscamos as ideias de Benjamin (2009) acerca da forma como as crianças lidam com a leitura literária. Em um de seus fragmentos - "Criança Lendo" - o filósofo escreve que no momento em que as crianças leem ou ouvem uma história, elas se misturam aos seus personagens, sentindo suas aventuras como reais:

Para ela as aventuras do herói são legíveis ainda no redemoinho das letras (...). Ela está misturada entre as personagens muito mais de perto que o adulto. É indizivelmente concernida pelo acontecer e pelas palavras trocadas e, quando se levanta, está totalmente coberta pela neve do lido (BENJAMIM, 1995, p. 37).

Ao refletir sobre este trecho, é possível perceber a compreensão de Benjamin sobre o que o mergulho na literatura pode causar à criança: para ele, a imaginação da criança parece caminhar para além das páginas do livro, permitindo a ela adentrá-lo pela via da fantasia, viver sua história e voltar desse mergulho "coberta pela neve do lido". Podemos notar que a aluna, pela fantasia, se encontrava no "rodamoinho das letras", totalmente tomada pelos acontecimentos do conto, sentindo-os tão de perto, que precisou tampar olhos e ouvidos para não ver mais: ainda estava envolta na neve, não do que tinha lido, mas do que ainda se estava lendo. Seus gestos evidenciam o que o filósofo chama de faculdade mimética: "o homem tem a capacidade suprema de produzir semelhança [...] e é na brincadeira infantil que a faculdade mimética pode ser observada" (BENJAMIN, p. 4) - estendendo-se igualmente aos movimentos que envolvem a leitura e que poderíamos denominar de leitura mimética.

Como Abramovich (1989) diria a escuta de histórias permite a criança sentir emoções importantes, como o medo, a raiva, a alegria, o pavor, etc. A menina, ao ouvir a narrativa literária, estava experimentando muitas emoções - expectativa, medo, pavor - e enfrentando-as como podia. E como compreendemos com Vigotski, a arte também deve ser capaz de abordar emoções contraditórias, de forma a construir um curto-circuito emocional no apreciador. O livro literário que estava sendo lido pela professora - como obra artística que é - foi capaz de provocar um curto circuito emocional na criança que com ele interagia, causando emoções que proporcionaram a ela deslocamentos e novas experiências.

Ainda chama atenção a forma como um dos alunos percebe a estratégia que a professora está prestes a empreender, de parar a história num momento chave para continuar depois, o que revela uma prática de leitura recorrente no compartilhamento de histórias entre a professora da sala de leitura e as crianças da escola. Sobre essa prática, poderíamos dizer que ela pode ser significativa, na medida em que estimula e aguça a curiosidade das crianças a respeito do desenrolar de uma narrativa mais extensa: diante de uma ou outra situação, os ouvintes poderão 
pensar coisas diferentes e, ao compartilhar suas ideias, rever e ampliar suas interpretações sobre a leitura em andamento. Não observamos isso acontecer com esta turma, mas com outras sim. Antes de continuar a história, Amélia costumava lembrar com as crianças onde haviam parado a leitura, novamente indagando sobre o que aconteceria a partir dali e abrindo espaço para que as vozes dos leitores se apresentassem. Observemos agora mais um evento capturado na pesquisa:

\footnotetext{
Conversando com Barba Azul: entre dotes e duques

Crianças estão muito atentas e bem envolvidas. No final da história, Amélia comenta sobre o dote que a moça da história teria que dar para se casar e coloca sua opinião: "Já pensou?! A mulher ter que dar dinheiro para o marido com quem vai se casar!" Depois explica melhor como funcionava essa questão do dote, em outros tempos, e diz: "Se meu pai tivesse que pagar um dote pra eu me casar, eu não tinha casado até hoje! Meu pai não tinha dinheiro! Tudo tinha que ser pago naquela época! Até pra ser capitão! Hoje não é mais assim, né?" Depois comenta sobre os personagens dos irmãos que viraram duques e continua a conversa (caderno de campo, 25/04/17) .
}

Para iniciarmos o diálogo sobre o recorte acima, trazemos as reflexões de Sisto (s/ano) sobre como as histórias quase sempre presenteiam os leitores e ouvintes com referências a épocas e costumes diversos:

Histórias narradas oralmente proporcionam às crianças uma visão epocal (ainda que de forma esboçada), seja do seu tempo, seja de outros tempos. O recorte oferecido pela história delineia sempre uma época, um conjunto de costumes, comportamentos, vivências, códigos de ações, uma ética, que acabam fazendo do texto esse complexo histórico (SISTO, s/ano, p. 2).

O conto "Barba Azul”, que Amélia compartilha com as crianças, é um conto tradicional, difundido entre as crianças desde o século XVII. Como qualquer narrativa, traz suas marcas histórico-sociais, relacionadas a valores, costumes, conhecimentos, comportamentos, papéis sociais, pensamentos, éticas: quando entram em contato com leitores de outros tempos, podem colocar passado, presente e futuro em diálogo, pois revelam outras visões de mundo. Como compreender um passado de "dotes" e "duques" no mundo de hoje, entre leitores crianças e de classes populares tão distantes social e culturalmente deles? Esta indagação nos faz novamente voltar às discussões de Cosson (2010) sobre o ensino da literatura e os espaços que ela deve ocupar na escola. Neste evento, por exemplo, pode-se observar que o espaço da leitura do texto foi garantido. Mas o espaço do contexto também se apresentou, na medida em que a professora ampliou o diálogo com a obra ao trazer referências de outros tempos e se posicionou sobre eles também. De acordo com Cosson (2010):

todo texto literário tem uma mensagem mais ou menos explícita, tem um desenho de mundo a ser depreendido no momento da leitura, um saber sobre essa ou aquela área 
que não pode e nem deve ser desprezado - trata-se do contexto da obra, entendendo que contexto, como bem adverte Manguineau (1995), não é o que está em volta da obra, mas, sim, as referências de mundo que ela traz consigo, o que vem com o texto (COSSON, 2010, p. 62).

O autor elucida que por conta do contexto que qualquer obra literária apresenta, muitas vezes ela é transformada em objeto de ensino de um determinado conteúdo e ressalta que de fato há obras que são escritas para esse fim, restringindo sua leitura a um uso escolar prédeterminado. São obras cujo ponto de sustentação não seria a vida de suas personagens, a elaboração da linguagem e o mundo que encena, mas, sim, um saber que seu contexto destaca. Cosson defende a ideia de que a exploração do contexto de uma obra faz parte do espaço da literatura na sala de aula, inclusive porque a literatura, ao dizer o mundo, pode por vezes envolver conhecimentos que também passam pela escola em outras disciplinas. Para o autor, revelar esses vínculos não prejudicaria a leitura literária, podendo, ao contrário, ser uma contribuição importante para ampliar o entendimento da narrativa que se está lendo, mas adverte que o uso do saber da obra literária não pertenceria ao espaço da literatura em sala de aula "quando se ignora o lugar onde está localizado, quando se acredita que a leitura desse contexto independe do texto, quando esse saber deixa de ser contextual" (COSSON, 2010, p. 63).

Ao pensar sobre o evento destacado, entendemos que a professora, ao dialogar com as referências de mundo que apareciam naquele texto literário, dialoga com conteúdos de ensino de História, embora ela não tenha escolhido o conto de Perrault por este motivo. Ao ler Barba Azul, trabalhou "com o texto" que nele se apresenta, com as referências que ele traz de outras épocas e culturas, ampliando conhecimentos dos leitores sobre conteúdos de História, certamente, mas, não restritos a eles. O diálogo com o contexto da obra, da maneira como aconteceu, ampliou a compreensão dos leitores a respeito da narrativa que se lia, fazendo-os indagar sobre o mundo de hoje e o contexto que nele se encontra.

Observa-se ainda o importante lugar ocupado pela professora no processo de interação entre seus ouvintes/leitores e a leitura que estes realizam, pois como Corsino (2010) reflete, é esse adulto/mediador "quem dá voz às crianças durante a leitura, [...] quem coloca pontos de vista em discussão, quem provoca argumentações, quem abre e acolhe múltiplas leituras" (p.187). Assim, na conversa que se seguiu à escuta da história e das ponderações da professora sobre dotes e duques daqueles tempos, percebemos sujeitos se expressando, sujeitos que estão no mundo e que apresentam diferentes formas de olhar, de estar e de lidar com ele. Vejamos a continuidade desse evento: 


\section{O que a mulher do Barba Azul fez com o dinheiro que recebeu?}

Amélia: "Vocês acham que eles (os irmãos) mereciam virar duques? Eles salvaram a irmã!"; / Crianças: "Sim!"

Amélia: E o que vocês acham que a mulher do Barba Azul fez com o dinheiro que recebeu? Aluna 1: Comprou vestidos! / Aluno 2: Gastou com um Big Mac. Aluna 3: Ela se casou! E arrumou toda a casa! / Aluna 4: Mas ela tirou todos aqueles corpos de lá, né Tia? / Amélia: É. Tirou. Limpou tudo. / Aluna 4: Ela não, né, tia? As empregadas dela...

Para Bakhtin (1988), é na relação com a alteridade que os sujeitos se constituem e se alteram constantemente, num processo que se consolida socialmente, por meio das interações, das palavras, dos signos. A experiência de leitura com o conto "Barba Azul" nos permitiu observar como as crianças se colocaram frente a diferentes situações apresentadas nele e seus possíveis desdobramentos. Na provocação da professora, impressões individuais eram agora partilhadas e confrontadas com as dos demais leitores. Nesse sentido, na interação verbal que se estabeleceu naquele momento e em diálogo com a palavra do outro, as crianças levantaram hipóteses, negociaram sentidos, apresentaram réplicas, se posicionaram, buscaram respostas, num movimento dialógico que ampliou a compreensão sobre a narrativa ouvida, sobre eles próprios, a sociedade, a cultura, o mundo. Assim, por exemplo, quando afirmam conjuntamente que os irmãos mereciam virar duques (pois tinham salvado a irmã) revelam e compartilham um olhar sobre o valor que se encontra em nossa sociedade, de que atos de bondade ou coragem merecem ser recompensados. Quando as crianças apresentam diferentes possibilidades de como utilizar o dinheiro ganho, falam também de si, de seus desejos, de coisas que consideram necessárias e que são diversas, pois como sujeitos diferentes, seus horizontes diferem de acordo com suas experiências. Por fim, no diálogo sobre a possibilidade de se casar e arrumar a casa, situação permitida pelo dinheiro recebido, um novo problema se apresenta: "Mas ela tirou todos aqueles corpos de lá, né Tia? / É. Tirou. Limpou tudo. / Ela não, né, tia? As empregadas dela...”. Ao negociar esses sentidos com a professora, a aluna, indagando o texto (pois a personagem, agora poderosa e rica, contaria com muitas empregadas para as tarefas da casa), indaga a própria sociedade e cultura da qual faz parte, revelando uma visão de que, nesse contexto, também são as empregadas que fazem trabalhos de arrumação de uma casa.

"Em cada texto que lê, o sujeito-leitor aumenta seu acervo podendo fazer novas leituras de si mesmo, do outro e do mundo", afirma Corsino (2010, p. 9), e foi o que observamos ao analisar estes eventos de pesquisa. Neles, o convite para adentrar e dialogar com o mundo da literatura se deu por meio de práticas sociais de leitura, tais como a leitura oralizada e as 
conversas sobre o que foi compartilhado. O convite também aconteceu nos modos da professora de se entregar à própria atividade de ler em voz alta e nos modos como ela conduzia essa leitura, interrogando os leitores e abrindo espaços para a troca de ideias ampliadoras da compreensão. Movimentos que se mostraram fundamentais para aproximar as crianças da literatura e que contribuíram para ampliar a experiência delas como sujeitos/leitores. E não seria esse o maior propósito de se ensinar a literatura na escola? O que, afinal, se deseja ensinar quando se compartilha a literatura na escola? Como reflete Britto:

O desafio pedagógico está, precisamente, em respeitar o gosto conhecido (admitindo, portanto, sua leitura de mundo) e, ao mesmo tempo, estimular a autonomia (recusando o autoritarismo da referência absoluta), sem perder a dimensão política da formação do leitor. Em outras palavras, ao propor uma leitura aos alunos, o professor deve considerar seu potencial de transcendência, de instigação de novas experiências e reflexões (2011, p. 22).

\section{Considerações finais}

Entrar no universo da literatura é entrar no mundo das palavras: num jogo de palavras que apela aos cinco sentidos e que nos permite criar cenas, lugares e pessoas: múltiplos universos e personagens com quem nos surpreendemos, identificamos, nos estranhamos, e cujos movimentos nos fazem sair do lugar, ver o mundo diferente, ampliar olhares, pensar, imaginar, sentir, indagar, descobrir, desejar. Ao ouvirmos ou lermos uma história, nos colocamos diante de um quadro ficcional que não diz respeito apenas aos personagens ali desenhados, mas se refere a todos nós, pelas emoções e sensações que suscita, possibilitando "a descoberta da vida como ela pode ser, para além das contingências do real imediato" (AGUIAR 2011, p. 122).

Mas como levar a literatura para a escola? Como compartilhá-la? Como experimentála? Como ensiná-la? Tentar responder a tais questionamentos foi o objetivo deste artigo, que teve como base investigações e análises realizadas numa tese de doutorado. Assim, foi importante, para situar nossas indagações e respostas, refletir sobre a relação entre leitura, literatura, experiência e escola e sobre os próprios conceitos de experiência, leitura e literatura. Como sabemos, qualquer prática escolar é atravessada por concepções e conceitos e, quando se pensa em práticas compartilhadas com crianças, torna-se muito importante pensar nas concepções de infância que nos guiam, sustentando nossas escolhas, nossos discursos e práticas. Por que ler e ensinar a ler literatura nas escolas? Como se ensina? Como se aprende? Como se experimenta a literatura na escola? O que ela é capaz de provocar? O que acontece e nos acontece quando lemos um texto literário para e com as crianças? Ao longo do texto, 
defendemos a ideia da leitura enquanto experiência que permanece no leitor, engendrando reflexões para além do momento em que acontece e que, nesse sentido, contribui para a formação do sujeito/leitor, sendo esta talvez a grande aprendizagem que podemos tirar do encontro com a literatura. E vimos que nas análises dos eventos apresentados, a experiência com a literatura foi mesmo capaz de deslocar os sujeitos, ampliar seus repertórios, fazê-los imaginar, sentir, pensar, provocando-os a dialogar com eles próprios, com o outro (o que inclui as próprias narrativas) e com o mundo.

Entendemos ainda que a escola é um espaço coletivo e que pode ser muito propício às trocas entre os diferentes sujeitos. Nesse sentido, pensar sobre as práticas sociais de leitura, as quais são apropriadas pela escola, foi fundamental para o desenvolvimento do artigo. Dentre elas, nos debruçamos com maior afinco sobre a leitura oral compartilhada e as rodas ou círculos de leitura. Além de problematiza-las, observamos como tais práticas, na dinâmica pedagógica de suas conduções, contribuíram para que as vozes dos leitores fossem expressas e ouvidas, promovendo o intercâmbio de ideias e ampliando os sentidos dos leitores frente ao texto literário que lhes era apresentado.

Nesse sentido, pensando na relação entre ensino e literatura, trouxemos também reflexões de Cosson (2010), nas quais o autor, além de defender a ideia de que todo modo de ler passa necessariamente por uma aprendizagem, disserta sobre diferentes usos que já foram feitos da literatura na escola, para, por fim, reivindicar um espaço próprio para a literatura na sala de aula: o espaço do texto, do contex to e do intertexto e que seriam meios e formas para se desenvolver o ensino da literatura na escola. De que modo, em outras palavras, aprendemos a ler o texto literário, uma vez que ler implica essencialmente na elaboração de sentidos? De que forma, os espaços reivindicados pelo autor promovem significativamente aprendizagens relacionadas à literatura?

Nas análises apresentadas, percebemos momentos em que tanto o espaço do texto, como do contexto, foram garantidos, seja por meio das práticas de leitura oral compartilhada, seja nas conversas que aconteceram a partir do texto lido. Vimos ainda o quanto foi importante para a construção de sentidos dos leitores, na leitura do conto Barba Azul, a mediação da professora que, entregue ao texto, se deixando também afetar por ele, não esquecia que o compartilhava com seus alunos, mantendo-se atenta aos movimentos deles, abrindo espaços para suas vozes e trazendo informações sobre o contexto social daquele conto. Tais movimentos da professora, em sua prática pedagógica, se mostraram essenciais para que as crianças vivenciassem a leitura 
enquanto experiência: elas se deslocarem a partir da palavra literária, levaram reflexões para além daquele momento e ampliaram sua formação como sujeitos/leitores.

\section{Referências}

ABRAMOVICH, Fanny. Literatura Infantil: gostosuras e bobices. São Paulo: Editora Scipione, 1989.

AMARILHA, Marly. Estão Mortas as Fadas? Literatura Infantil e Prática Pedagógica. Petrópolis: Ed. Vozes, 1997.

AGUIAR, V. T. O compromisso de fazer literatura para crianças e jovens. In: OLIVEIRA, Ieda de (org.). O que é qualidade em literatura infantil e juvenil? São Paulo: DCL, 2011.

BAKHTIN, Mikhail (Volochinov). Marxismo e Filosofia da Linguagem: problemas fundamentais do método sociológico da linguagem. São Paulo: Hucitec, 1988.

BAJOUR, Cecília. Ouvir nas entrelinhas - o valor da escrita nas práticas de leitura. São Paulo: Editora Pulo do Gato. 2013

BENJAMIN, Walter. Obras Escolhidas vol. I. Magia e Técnica, Arte e Política. São Paulo: Brasiliense, 1994.

BENJAMIN, Walter. Obras escolhidas II: Rua de mão única. São Paulo: Brasiliense, 2009.

BRANDÃO, A. C. P.; ROSA, E. C. S. A leitura de textos literários na sala de aula: é conversando que a gente se entende. In: PAIVA, Aparecida (org.). Coleção explorando o ensino. Literatura: ensino fundamental. Brasília: Ministério da Educação, Secretaria de educação básica, 2010, p. 69-88.

BRITTO, Percival. Inquietudes e desacordos: a leitura além do óbvio. Campinas, SP: Mercado de Letras, 2012.

BRITTO, Percival. Letramento e Alfabetização: implicações para a educação infantil. In: FARIA A. L. G.; Melo A. S. (orgs.). O mundo da escrita e o universo da pequena infância. Campinas: São Paulo. Autores Associados, 2005 - p. 05-21.

CABRAL, Márcia. Leitura: história e histórias. In: Cursos da Casa da Leitura - Biblioteca e mediação da leitura. Rio de Janeiro: Fund. da Biblioteca Nacional. 2008.

CHARTIER, Roger. A aventura do livro - do leitor ao navegador. Editora Unesp. São Paulo, 2009.

COSSON, Rildo. Letramento Literário: teoria e prática. São Paulo: Contexto, 2006. 
CORSINO, Patrícia. O espaço da Literatura na sala de aula. In: PAIVA, Aparecida (org.). Coleção explorando o ensino. Literatura: ensino fundamental. Brasília: Ministério da Educação, Secretaria de educação básica, 2010, p. 55-68.

CORSINO, Patrícia. Literatura na Educação Infantil: possibilidades e ampliações. In: PAIVA, Aparecida (org.). Coleção explorando o ensino. Literatura: Ensino Fundamental. Brasília: Ministério da Educação. 2010.

CORSINO, Patrícia, TRAVASSOS, S. e VILELA, R. Reflexões sobre políticas de livro e leitura de secretarias municipais de educação do Estado do Rio de Janeiro. In: Revista Estudos da Literatura Brasileira Contemporânea, $n^{\circ} 50$ - Lugares do Literário - 2017. Visualizado em: http://periodicos.unb.br/index.php/estudos/article/view/24152 - janeiro/2017.

CUNHA, Maria Zilda. Estética do labirinto na produção para crianças e jovens: de estratégias de leitura aos desafios para medir a astúcia do viajante. Pág. 121-141. In: FILHO J.N. G.; PINA P. K. C.; MICHELLI Regina Silva (orgs.). A Literatura infantil e juvenil hoje: múltiplos olhares, diversas leituras. Rio de Janeiro: Dialogarts, 2011.

DEBUS, Eliane. As condições de produção da Leitura Literária na Educação Infantil. Dobras de Leitura - Ano III - N. ${ }^{\circ} 9$ - abr.mai.jun. 2002 - s/n

GOULART, Cecília. Alfabetização e letramento: os processos e o lugar da literatura. In: PAIVA, et all. (Orgs). Literatura: saberes em movimento. Belo Horizonte: Autêntica, Ceale, 2007, p. 57-67.

KRAMER, Sonia. Leitura, experiência e formação. In: Cursos da Casa da Leitura. Rio de Janeiro: Biblioteca Nacional, 2009, p. 32-39.

PERROTTI, Edmir. Confinamento Cultural, Infância, Leitura. São Paulo: Summus, 1990.

PIMENTEL, Claudia. O livro na educação infantil: dialogando com relatórios de estágio. In: Anais do III Congresso GRUPECI. Universidade Federal de Sergipe. Aracaju: 2012.

REYES, Yolanda. A substância oculta dos contos. O ensino de literatura na escola. In: Revista Emília. Fevereiro de 2012. Ver em: http://www.revistaemilia.com.br/mostra.php?id=137. Acesso em dezembro de 2012.

RODARI, Gianni. Gramática da Fantasia. São Paulo: Summus, 1982.

SILVA, Luiz Antonio. Criar práticas leitoras: uma provocação à reflexão teórica e um desafio social. In: Cursos da Casa da Leitura - Biblioteca e mediação da leitura. Rio de Janeiro: Fundação da Biblioteca Nacional, 2008.

SISTO, Celso. A Arte de contar histórias e sua importância no desenvolvimento infantil. In: Site: artistasgaúchos.com.br. Disponível em: www.artistasgaúchos.com.br. Visualizado em: janeiro e 2017.

TRAVASSOS, Sonia. Biblioteca Escolar: muito além de estantes arrumadas. In: Cursos da Casa da Leitura - Biblioteca e mediação da leitura. Rio de Janeiro: Fundação da Biblioteca Nacional. 2010. 
VARGAS, Laerte. Contar histórias: será que eu levo jeito? In: Revista Sinpro-Rio; $n^{o} 03$, junho 2008. Rio de Janeiro: Sinpro-Rio, 2008.

YUNES, Eliana. Tecendo um leitor: uma rede de fios cruzados. Curitiba: Aymará, 2009.

Recebido em 30 de agosto de 2019.

Aceito em 16 de novembro de 2019. 